Research article Open Access

\title{
Triple-negative breast cancers are increased in black women regardless of age or body mass index
}

\author{
Lesley A Stead ${ }^{1}$, Timothy L Lash ${ }^{1}, 2$, Jerome E Sobieraj ${ }^{1}$, Dorcas D Chi', Jennifer L Westrup ${ }^{1}$, \\ Marjory Charlot ${ }^{1}$, Rita A Blanchard ${ }^{1}$, John C Lee ${ }^{3}$, Thomas C King ${ }^{3}$ and Carol L Rosenberg ${ }^{1,3}$
}

\author{
${ }^{1}$ Department of Medicine, Boston University Medical Center, 650 Albany Street, Boston, MA 02118, USA \\ 2Department of Epidemiology, Boston University School of Public Health, 715 Albany Street, Talbot Building, Boston, MA 02118, USA \\ ${ }^{3}$ Department of Pathology and Laboratory Medicine, Boston University Medical Center, 650 Albany Street, Boston, MA 02118, USA \\ Corresponding author: Carol L Rosenberg, crosenbe@bu.edu
}

Received: 20 Oct 2008 Revisions requested: 19 Nov 2008 Revisions received: 17 Feb 2009 Accepted: 25 Mar 2009 Published: 25 Mar 2009

Breast Cancer Research 2009, 11:R18 (doi:10.1186/bcr2242)

This article is online at: http://breast-cancer-research.com/content/11/2/R18

(c) 2009 Stead et al.; licensee BioMed Central Ltd.

This is an open access article distributed under the terms of the Creative Commons Attribution License (http://creativecommons.org/licenses/by/2.0), which permits unrestricted use, distribution, and reproduction in any medium, provided the original work is properly cited.

\begin{abstract}
Introduction We investigated clinical and pathologic features of breast cancers (BC) in an unselected series of patients diagnosed in a tertiary care hospital serving a diverse population. We focused on triple-negative (Tneg) tumours (oestrogen receptor (ER), progesterone receptor (PR) and HER2 negative), which are associated with poor prognosis.
\end{abstract}

Methods We identified female patients with invasive BC diagnosed between 1998 and 2006, with data available on tumor grade, stage, ER, PR and HER2 status, and patient age, body mass index (BMI) and self-identified racial/ethnic group. We determined associations between patient and tumour characteristics using contingency tables and multivariate logistic regression.

Results 415 cases were identified. Patients were racially and ethnically diverse (born in 44 countries, $36 \%$ white, $43 \%$ black, $10 \%$ Hispanic and $11 \%$ other). $47 \%$ were obese (BMI > $30 \mathrm{~kg} /$ m2). $72 \%$ of tumours were ER+ and/or PR+, $20 \%$ were Tneg and $13 \%$ were HER2+. The odds of having a Tneg tumour were 3 -fold higher (95\% Cl 1.6, 5.5; $p=0.0001)$ in black compared with white women. Tneg tumours were equally common in black women diagnosed before and after age 50 (31\% vs 29\%; $p=$ NS), and who were obese and non-obese (29\% vs $31 \% ; p=$ NS). Considering all patients, as BMl increased, the proportion of Tneg tumours decreased $(p=0.08)$.

Conclusions Black women of diverse background have 3-fold more Tneg tumours than non-black women, regardless of age and BMI. Other factors must determine tumour subtype. The higher prevalence of Tneg tumours in black women in all age and weight categories likely contributes to black women's unfavorable breast cancer prognosis.

\section{Introduction}

Breast cancer is a clinically and genetically heterogeneous disease, varying substantially in incidence and mortality according to race/ethnicity [1]. To better understand the clinical and pathological features associated with breast cancer, we created a database of all invasive breast cancer patients seen at our institution. The Boston University Medical Center includes a tertiary-care hospital that is the largest safety net provider in New England and provides care to a diverse population. Approximately $75 \%$ of patients are insured under gov- ernment-funded programs (e.g., Medicaid or Medicare) or receive free care. One-half have an annual income below $\$ 20,420$ and $30 \%$ do not speak English (medical interpreters deliver translation in 60 languages). The institution's patients includes self-identified ethnic groups in the following proportions: 36\% black, 32\% white, 16\% hispanic, 4\% Asian and $13 \%$ other. "Asian" here includes most South-East Asian nationalities, except Thailand, Singapore, Taiwan. Those nationalities, along with Indian, are included in "other".

BMI: body mass index; Cl: confidence intervals; EGFR: epidermal growth factor receptor; EMR: electronic medical record; ER: oestrogen receptor; FISH: fluorescence in situ hybridisation; HER: human epidermal growth factor receptor; NOS: not otherwise specified; NS: not significant; OR: odds ratios; PR: progesterone receptor. 
In the present study, we used the database to examine the incidence of triple-negative breast cancers and their associated clinical and pathological features.

The triple-negative immunophenotype, that is, oestrogen receptor (ER), progesterone receptor (PR) and human epidermal growth factor receptor (HER) 2 negative, constitutes approximately $15 \%$ of all invasive breast cancers. It is often categorised as a basal-like tumour, a distinct biological subtype identified by gene expression. Many basal-like tumours express cytokeratins (CK) 5, 6 and 17 as well as HER1 (epidermal growth factor receptor (EGFR) [2]. Basal-like tumours are associated with aggressive histological features [3], BRCA mutation carriers [4] and poor prognosis [4,5]. Basallike tumours are more common in premenopausal AfricanAmerican women compared with postmenopausal AfricanAmerican women or non-African-American women [6]. These reports led us to investigate the proportions of triple-negative tumours in our ethnically heterogeneous population and to evaluate whether these triple-negative tumours also belonged to the basal-like subtype.

In addition, we queried whether body mass index (BMI) was associated with triple-negative tumours. Elevated BMI has been shown to be associated with an increased risk of hormone receptor-positive breast cancer in postmenopausal women $[7,8]$. In general, obesity has been shown to be associated with an increased risk of breast cancer and decreased survival [9], with a worse prognosis in both pre- and postmenopausal women $[10,11]$. Both white [12-14] and black premenopausal women [15] have modest inverse associations between body weight and breast cancer incidence $[16,17]$. Postmenopausal obese women have an increased risk of developing breast cancer and decreased survival $[18,19]$.

The overall incidence of breast cancer among black women in the USA is lower than in white women [20]. However, black women are more likely to have advanced stage of disease at diagnosis, higher risk of recurrence and worse overall prognosis [21-23]. The reasons for this difference are likely to be multifactorial. Some studies suggest that one factor may be a variation in obesity and body fat distribution between black and white women [24-26]. There are few reports on the associations between race/ethnicity, BMI, age and breast cancer subtypes. Reports on the relation between BMI and triple-negative breast cancer specifically are even fewer. To elucidate potential relations, we investigated associations between clinical features (race/ethnicity, BMI, age) and tumour characteristics (grade, ER, PR and HER2 status, nodal involvement).

\section{Materials and methods Study population}

With Institutional Review Board approval, we established a database of all female patients diagnosed at our institution with invasive breast cancer between March 1998 and Novem- ber 2006. Informed consent was waived because individual patient information was identified only by investigator-generated code numbers that are not linkable to patient identifiers. For each patient, we identified tumour grade, stage, level of ER, PR and HER2 expression (or gene amplification), patient age, BMl (using standard National Heart, Lung and Blood Institute categories) and self-identified racial group. Recurrent tumours were excluded. (Recurrence was defined by time elapsed since first tumour, interim treatment, immunophenotype, histology, metastases and clinical impression). Ten of 415 tumours (2\%) were second primary or synchronous contralateral breast tumours and were included in this study.

\section{Data collection}

We queried electronic medical records (EMR) and performed manual medical record review for all patients to ensure quality control. Tumour histology, grade, stage, ER, PR and HER2 expression were determined from the original pathology reports. Tumours had been diagnosed by experienced pathologists using standard criteria for histology and modified Scarff-Bloom-Richardson criteria for grade. ER and PR expression were determined using immunoperoxidase staining (Dako, Carpinteria, CA, USA) and quantified by image analysis (Biogenex, San Ramon, CA, USA) with values less than 5\% categorised as negative. HER2 expression was determined by immunohistochemistry (Dako, Carpinteria, CA, USA). Tumours that showed 2+ Her2/neu immunohistochemistry staining based on HercepTest criteria were definitively assessed by fluorescence in situ hybridisation (FISH) (Vysis, Des Plaines, IL, USA). Tumours were designated as being HER2+ if they showed 3+ Her2/neu immunohistochemistry staining (based on HercepTest criteria) or if they were FISH positive $[27,28]$. Stage at diagnosis was coded according to the American Joint Commission on Cancer's Cancer Staging Manual [29].

Patient age at diagnosis was calculated using the dates of birth and diagnosis in the EMR. Patients were categorised as diagnosed at age 50 years or younger, when they are more likely to be premenopausal, or at age over 50 years, when they are more likely to be postmenopausal. BMI was calculated by weight $(\mathrm{kg}) /$ height squared $\left(\mathrm{m}^{2}\right)$ using EMR data. In $97 \%$ of cases, weight and height were recorded within six months of diagnosis. If more than one weight or height value was available, we used the values closest to the date of diagnosis. Patients were placed into one of five BMl categories: under/ normal weight $(\mathrm{BMI}<25)$, overweight (BMI 25 to $<30$ ), obesity I (BMI 30 to $<35$ ), obesity II (BMI 35 to $<40$ ) or obesity III $(B M I \geq 40)$.

Racial/ethnic group was determined by patient self-identification at the time of registration. Categories included: white/caucasian, black/African-American, hispanic, Asian/Pacific Islander, Middle Eastern and other. Due to sparse data, patients self-identified as Asian or Middle Eastern were included in the other category. To test the accuracy of the 
registration data, a manual review of the EMR was performed to determine provider-identified racial/ethnic group. A provider-identified racial/ethnic group was available for 402 of 415 patients and was concordant with the self-identified group in $91 \%$ of cases. When groups differed, the self-identified group was used. EMR data often included country of origin.

Because women born in the Caribbean constituted a large subgroup of our black population ( $n=56,27 \%$ ), we compared this subgroup to the rest of the black population, which comprised patients who were provider-identified as AfricanAmerican, African or black without further specification. Our Caribbean black patients were from countries with a majority pan-West African origin (Haiti, Jamaica, Trinidad, Tobago, Barbados and Montserrat). Patients from the Caribbean countries with a majority hispanic origin (Dominican Republic, Puerto Rico and Cuba) were classified as hispanic and not included in this black subgroup comparison.

\section{Morphology and immunohistochemistry}

For 56 of the 81 triple-negative tumours, residual paraffinembedded tumour tissue was available and additional evaluation could be performed. For additional morphological assessment, tumours were classified as grade 2 or grade 3 ductal carcinoma not otherwise specified (NOS), medullary-like carcinoma or other (for example, grade 1 ductal NOS, lobular or micropapillary tumours). Additional immunohistochemistry was performed with antibodies to CK 5/6 (Biocare Medical, Concord, CA, USA), and EGFR (Dako, Carpinteria, CA, USA) using a streptavidin-biotin horseradish peroxidase detection kit (Biogenex, San Ramon, CA, USA). The expression of these markers was graded semi-quantitatively. Allred scoring [30] was used for $\mathrm{CK5} / 6$, with a score of 5 or more considered as positive. HercepTest scoring criteria [27] were used to grade EGFR expression, with a score of $2+$ or more considered as positive [31].

\section{Statistical analysis}

Data on patient and tumour characteristics were entered into a Microsoft Excel worksheet (Redmond, WA, USA) and exported into the SAS (Cary, NC, USA) statistical package. We used chi-squares statistics based on contingency tables to test for homogeneity of proportions and multivariate logistic regression to determine associations between patient-tumour characteristics and triple-negative breast cancer. Odds ratios (OR) and 95\% confidence intervals $(\mathrm{Cl})$ from the multivariate logistic regression analyses were adjusted for race, BMI and age $(\leq 50$ or $>50$ ). We investigated whether there was an adjusted association between categorical variables (race and BMI group) and triple-negative tumour type by calculating twice the difference in the model log-likelihood with and without the categorical variable. This was distributed as chisquared with degrees of freedom equal to the number of categories less one. Women with missing data were excluded from these analyses.

\section{Results \\ Patient characteristics}

The demographic features of the 415 patients in our database are presented in Table 1. Some features are consistent with averages for the USA, but our population is unusual compared with most other reported cohorts because of its marked ethnic and racial diversity (Figure 1). In the present analysis, we

Figure 1

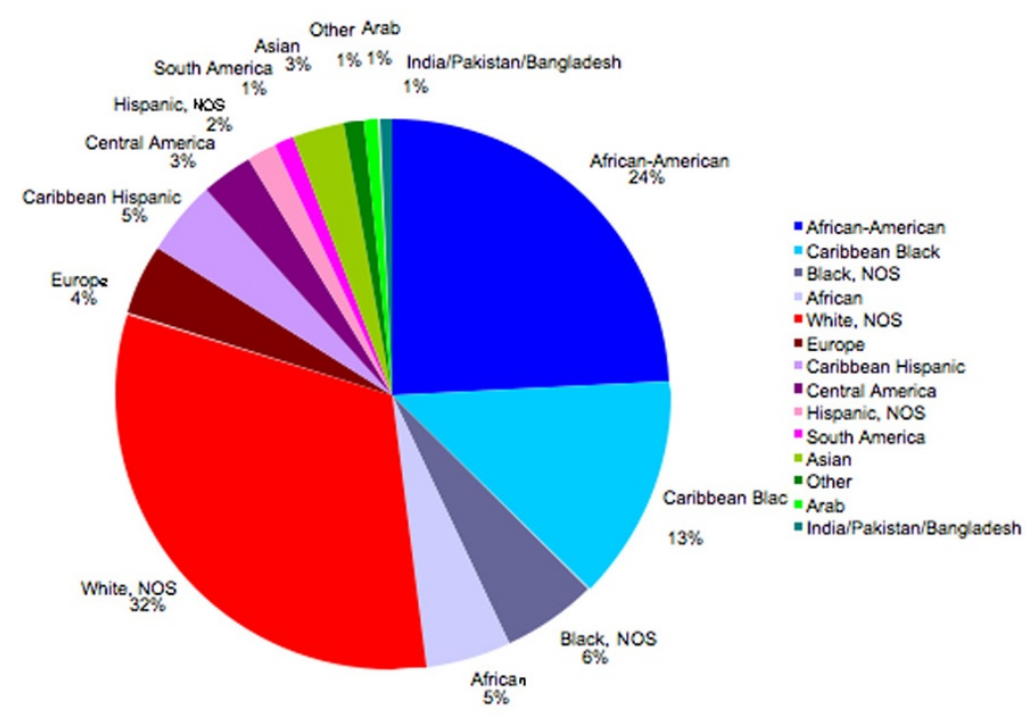

Distribution of breast cancer patients by race/ethnicity. The chart depicts the proportion of patients by race/ethnicity, classifying them by region of origin. NOS, not otherwise specified. 
Table 1

\begin{tabular}{|c|c|c|c|c|c|}
\hline Category (p-value)* & White & Black & Hispanic & Other & All \\
\hline & & & $\mathrm{N}(\%)$ & & \\
\hline Race & $148(36)$ & $177(43)$ & $43(10)$ & $47(11)$ & 415 \\
\hline \multicolumn{6}{|l|}{ Age (years) (0.04) } \\
\hline$\leq \mathbf{5 0}$ (premenopausal) & $37(25)$ & $53(30)$ & $20(47)$ & $15(32)$ & 125 (30) \\
\hline$>50$ (postmenopausal) & $111(75)$ & $124(70)$ & $23(53)$ & $32(68)$ & $290(70)$ \\
\hline ER positive $(0.0003)$ & $115(80)$ & $104(59)$ & $35(81)$ & $35(74)$ & $289(70)$ \\
\hline PR positive $(<0.0001)$ & $105(72)$ & $90(51)$ & $36(84)$ & $22(47)$ & $253(62)$ \\
\hline Her2 positive $(0.03)$ & $11(7.5)$ & $26(15)$ & $5(12)$ & $11(23)$ & $53(13)$ \\
\hline Triple negative $(0.0002)$ & $19(13)$ & $52(30)$ & $5(12)$ & $5(11)$ & $81(20)$ \\
\hline \multicolumn{6}{|l|}{ Grade $(0.01)$} \\
\hline 1 & $27(19)$ & $14(8.5)$ & $7(16)$ & $6(13)$ & $54(14)$ \\
\hline 2 & $70(49)$ & $72(44)$ & $20(46)$ & $14(31)$ & $176(45)$ \\
\hline 3 & $45(32)$ & $78(48)$ & $16(37)$ & $25(56)$ & $164(42)$ \\
\hline \multicolumn{6}{|l|}{ T (tumour size) (0.64) } \\
\hline 1 & $76(58)$ & $94(58)$ & $22(54)$ & $22(52)$ & $214(57)$ \\
\hline 2 & 44 (33) & $56(35)$ & $12(29)$ & $15(36)$ & $127(34)$ \\
\hline 3 & $9(6.8)$ & $12(7.4)$ & $6(15)$ & $4(9.5)$ & $31(8)$ \\
\hline 4 & $3(2.3)$ & $0(0)$ & $1(2.4)$ & $1(2.4)$ & $5(1)$ \\
\hline \multicolumn{6}{|l|}{ No. of positive nodes $(0.50)$} \\
\hline 0 & $64(59)$ & $66(47)$ & $18(56)$ & $22(56)$ & $170(53)$ \\
\hline 1 to 3 & $27(25)$ & $43(31)$ & $11(34)$ & $8(21)$ & $89(28)$ \\
\hline 4 to 9 & $11(10)$ & $20(14)$ & $2(6)$ & $8(21)$ & $41(13)$ \\
\hline$\geq 10$ & $6(6)$ & $11(8)$ & 1 (3) & $1(3)$ & $19(6)$ \\
\hline \multicolumn{6}{|l|}{ BMI $\left(\mathrm{kg} / \mathrm{m}^{2}\right)(0.01)$} \\
\hline Underweight/normal & $39(27)$ & $32(18)$ & $5(12)$ & $19(40)$ & $95(23)$ \\
\hline Overweight & $45(31)$ & $47(27)$ & $19(44)$ & $11(23)$ & $122(30)$ \\
\hline Obesity I & $32(22)$ & $55(31)$ & $11(26)$ & $13(27)$ & $111(27)$ \\
\hline Obesity II & $20(14)$ & $26(15)$ & $3(7)$ & $2(4.3)$ & $51(13)$ \\
\hline Obesity III & $7(4.9)$ & $15(8.6)$ & $5(12)$ & $2(4.3)$ & $29(7)$ \\
\hline
\end{tabular}

* test of homogeneity of proportions

$\mathrm{BMI}=$ body mass index; $\mathrm{ER}=$ oestrogen receptor; HER = human epidermal growth factor receptor; PR $=$ progesterone receptor.

grouped patients into four racial/ethnic categories: white $(36 \%)$, black (43\%), hispanic (10\%) and other (11\%). Within these broad categories, our patient population contained diverse subcategories. The median age at diagnosis of invasive breast cancer in our patients was 58 years, which is slightly younger than the US average age of 61 years, as reported in the National Cancer Institute's SEER Cancer Sta- tistics Review [32]. Of our patients, $29 \%$ were 50 years or younger and $71 \%$ were older than 50 years at diagnosis. These proportions are generally consistent with US averages [33]. Notable in our population was the frequency of elevated BMI (only $23 \%$ of women fell into the under/normal weight category, while $30 \%$ were overweight, $27 \%$ were classified as obesity I, $13 \%$ as obesity II and $7 \%$ as obesity III). 


\section{Tumour characteristics}

Tumour characteristics are presented in Table 1. Of the 415 invasive breast cancers in our database, 81 (20\%) were triple negative, 297 (72\%) were ER and/or PR positive and 53 (13\%) were HER2 positive. Overall, our patients had fewer HER2-positive tumours and more triple-negative tumours than in some series, although our proportions are consistent with those in racially/ethnically heterogeneous cohorts [34-36]. In addition, our patients presented at a somewhat later stage than average for the USA: $47 \%$ of our tumours were lymph node-positive; the USA average is 39\% [32]. However, the presence of 96 tumours with unconfirmed node status may have affected these proportions.

We characterised all available triple-negative tumours (56 of $81(69 \%))$ with additional morphological classification and immunohistochemical staining for CK5/6 and EGFR to determine what proportion of the triple-negative tumours had the basal-like phenotype. We found that 19 of 56 (34\%) tumours were medullary-like, 14 of 56 (25\%) were grade 2 and 18 of $56(32 \%)$ were grade 3 ductal carcinoma NOS and 5 of 56 (9\%) were of other histologies. Of 56 tumours, 38 (68\%) were CK5/6 and/or EGFR positive. There was a significant association between CK5/6 expression and EGFR expression with a Spearman correlation coefficient of $0.34(p=0.01)$. Taken together, these studies suggest that our triple-negative tumours include a high proportion of basal-like tumours.

\section{Patient-tumour associations}

We examined associations between race, BMI, age (and presumed menopausal status), tumour grade, ER expression, PR expression, HER2 expression and nodal involvement. We confirmed previously noted associations between patient and tumour variables, for example, positive associations between markers of poor prognosis (e.g., grade and stage). Of particular relevance, we found in bivariate analyses that obesity was associated with race $(p=0.01)[15,37]$ and that triple-negative status was associated with race $(p=0.0002)[6,34-$ $36,38,39]$.
Table 1 shows the associations of race/ethnicity with tumour prognostic markers and other clinicopathological features. We noted two associations pertinent to triple-negative tumours and BMI. First, $30 \%$ of tumours in black women were triple negative, compared with 11 to $13 \%$ of tumours in other women. Second, $55 \%$ of black women were obese, compared with 36 to $45 \%$ of other women. There was no substantial dependence on race/ethnicity categories other than black (Table 1): the results of our analyses did not substantially depend on more finely-divided race categories, as determined by visual examination of the associations and their intervals with the reference category limited to whites versus the reference category defined as non-blacks. Therefore, we combined white, hispanic and other race/ethnicity categories into a single category 'non-black', which serves as our reference group, to address two questions.

Black women were both more likely than other women to be obese and to have triple-negative tumours, so we asked whether obese black women had a higher proportion of triplenegative tumours than other obese women. As shown in Table 2 , stratifying the dataset to black vs. non-black women, we found that $29 \%$ of obese black women had triple-negative tumours compared with $8.6 \%$ of obese non-black women (OR $=4.3: 95 \mathrm{Cl}=1.8$ to $10 ; \mathrm{p}=0.0004$ ). (Using whites as the reference category, the $\mathrm{OR}=4.2$ and $95 \% \mathrm{Cl}=1.6$ to 13 ). Similarly, $31 \%$ of non-obese black women had triple-negative tumours compared with $15 \%$ of non-obese non-black women (OR $=2.7,95 \% \mathrm{Cl}=1.4$ to $5.3 ; \mathrm{p}=0.003$ ). (Using whites as the reference category, the $\mathrm{OR}=2.5$ and $95 \% \mathrm{Cl}=1.2$ to 5.4). These two ORs were not significantly different from one another $(p=0.41)$, suggesting that among black women, BMI does not appear to be associated with triple-negative status.

Next, we examined associations of age at diagnosis with tumour characteristics within black and non-black women (Table 3). In contrast to previous reports $[6,40]$, we did not find a strong association between triple-negative tumour status and younger age when we considered all patients (24\% triple-

Table 2

Association between triple-negative breast cancer and race/ethnicity within strata of obese and non-obese women.

\begin{tabular}{|c|c|c|c|c|}
\hline & \multicolumn{2}{|c|}{$\begin{array}{c}\text { Black } \\
\text { n/total }(\%)\end{array}$} & \multicolumn{2}{|c|}{$\begin{array}{l}\text { Non-black } \\
\text { n/total (\%) }\end{array}$} \\
\hline & $\mathrm{BMI} \geq 30$ & $\mathrm{BMI}<30$ & $\mathrm{BMI} \geq 30$ & $\mathrm{BMI}<30$ \\
\hline \multicolumn{5}{|l|}{ Tumour immunophenotype } \\
\hline Triple negative & $27 / 94(29)$ & 25/79 (32) & 8/93 (8.6) & 20/137 (15) \\
\hline Other & $67 / 94(71)$ & $54 / 79(68)$ & $85 / 93(91)$ & $117 / 137(85)$ \\
\hline $\begin{array}{l}\text { Adjusted odds ratio of triple-negative tumour } \\
\text { (confidence interval) }\end{array}$ & $\begin{array}{c}4.3 \\
(1.8 \text { to } 10)\end{array}$ & $\begin{array}{c}2.7 \\
(1.4 \text { to } 5.3)\end{array}$ & 1.0 & 1.0 \\
\hline
\end{tabular}

$\mathrm{BMI}=$ body mass index. 
Table 3

\begin{tabular}{|c|c|c|c|c|}
\hline \multirow[b]{2}{*}{ Patient/tumour characteristic ( $p$-value ${ }^{\star}$ ) } & \multicolumn{2}{|c|}{ Black } & \multicolumn{2}{|c|}{ Non-black } \\
\hline & $\begin{array}{c}\text { age } \leq 50 \text { years } \\
\text { (premenopausal) }\end{array}$ & $\begin{array}{c}\text { age }>50 \text { years } \\
\text { (postmenopausal) }\end{array}$ & $\begin{array}{c}\text { age } \leq 50 \text { years } \\
\text { (premenopausal) }\end{array}$ & $\begin{array}{c}\text { age }>50 \text { years } \\
\text { (postmenopausal) }\end{array}$ \\
\hline & n (\%) & n (\%) & $\mathrm{n}(\%)$ & $\mathrm{n}(\%)$ \\
\hline \multicolumn{5}{|l|}{ BMI (0.03) } \\
\hline Underweight/normal $(<25)$ & $10(20)$ & $22(17)$ & $23(33)$ & $40(24)$ \\
\hline Overweight $(25$ to $<30)$ & $16(31)$ & $31(25)$ & $20(29)$ & $55(32)$ \\
\hline Obesity I (30 to <35) & $13(25)$ & $42(33)$ & $14(20)$ & $42(25)$ \\
\hline Obesity II (35 to <40) & $4(7.8)$ & $22(17)$ & $9(13)$ & $16(9.4)$ \\
\hline $\begin{array}{l}\text { Obesity III ( } \geq 40) \\
\text { Missing }\end{array}$ & $\begin{array}{l}8(16) \\
0(0)\end{array}$ & $\begin{array}{l}7(5.6) \\
2(1.6)\end{array}$ & $\begin{array}{l}2(2.9) \\
1(1.5)\end{array}$ & $\begin{array}{l}12(7.1) \\
5(2.9)\end{array}$ \\
\hline \multicolumn{5}{|l|}{ Immunophenotype $(<0.0001)$} \\
\hline Triple negative & $16(31)$ & $36(29)$ & $12(17)$ & $17(10)$ \\
\hline $\begin{array}{l}\text { Other } \\
\text { Missing }\end{array}$ & $\begin{array}{c}35(69) \\
0(0)\end{array}$ & $\begin{array}{l}8(70) \\
2(1.6)\end{array}$ & $\begin{array}{l}56(81) \\
1(1.5)\end{array}$ & $\begin{array}{l}151(89) \\
2(1.2)\end{array}$ \\
\hline \multicolumn{5}{|l|}{ Grade (0.06) } \\
\hline 1 & $3(5.9)$ & $11(8.7)$ & $13(19)$ & $27(16)$ \\
\hline 2 & $19(37)$ & $53(42)$ & $25(36)$ & $80(47)$ \\
\hline $\begin{array}{l}3 \\
\text { Missing }\end{array}$ & $\begin{array}{l}26(51) \\
3(5.9)\end{array}$ & $\begin{array}{l}52(41) \\
10(7.9)\end{array}$ & $\begin{array}{c}30(44) \\
1(1.5)\end{array}$ & $\begin{array}{l}56(33) \\
7(4.1)\end{array}$ \\
\hline \multicolumn{5}{|l|}{ Nodal involvement (0.03) } \\
\hline Node negative & $13(25)$ & $48(38)$ & $31(45)$ & $51(30)$ \\
\hline $\begin{array}{l}\text { Node positive } \\
\text { Missing }\end{array}$ & $\begin{array}{l}29(57) \\
9(18)\end{array}$ & $\begin{array}{l}52(41) \\
26(21)\end{array}$ & $\begin{array}{l}30(43) \\
8(12)\end{array}$ & $\begin{array}{l}71(42) \\
48(28)\end{array}$ \\
\hline Total number (\%) of all patients & $51(12)$ & $126(30)$ & $69(17)$ & $170(41)$ \\
\hline
\end{tabular}

* test of homogeneity of proportions.

$\mathrm{BMI}=$ body mass index.

negative tumours in women aged $\leq 50$ years compared with $18 \%$ triple-negative women aged $>50$ years; $p=0.22$ ). Adjustment for more finely divided age categories made no difference in the estimates of association. We next considered black vs. non-black women. We found that the proportions of triple-negative tumours were similar in younger and older black women: $31 \%$ of black women aged 50 years or younger and $29 \%$ of black women aged over 50 years had triple-negative tumours $(p=0.76)$. In contrast, we found a marginal association between triple-negative tumours and age in non-black women: $17 \%$ of non-black women aged 50 years or younger had triple-negative tumours, compared with $10 \%$ of non-black women aged over 50 years $(p=0.11)$.

To further characterise the possible relations between race/ ethnicity, BMI and triple-negative breast cancer, we performed multiple logistic regression analyses. Table 4 shows the adjusted $\mathrm{OR}$ and $95 \% \mathrm{Cl}$ from the multiple logistic regression analyses for patient characteristics of triple-negative breast cancers compared with other types of breast cancer. The odds of having a triple-negative tumour were three-fold higher $(95 \% \mathrm{Cl}=1.6$ to 5.4$)$ in black women as compared with white women. Mutually adjusting for race/ethnicity, BMI and age (age $\leq 50$ years vs. $>50$ years, as a surrogate for menopausal status), there remained a strong association between race/ethnicity and triple-negative tumours $(p=0.0001)$. After adjusting for race/ethnicity and age, we noted decreasing proportions of triple-negative tumours with increasing category of BMl $(p=0.08)$.

Because women of Caribbean origin constituted a large proportion of our black population ( $n=56,27 \%$ ), we compared 


\begin{tabular}{|c|c|c|c|c|}
\hline $\begin{array}{l}\text { Characteristics predicting } \\
\text { triple negative phenotype }\end{array}$ & n (\%) & $\begin{array}{l}\text { Adjusted } \\
\text { odds ratio§ }\end{array}$ & $95 \% \mathrm{Cl}$ & p-value* \\
\hline Race & & & & 0.0001 \\
\hline Black & $177(43)$ & 3.00 & 1.6 to 5.4 & \\
\hline White & $148(36)$ & 1.00 & reference & \\
\hline Hispanic & $43(10)$ & 0.83 & 0.28 to 2.4 & \\
\hline Other & $47(11)$ & 0.79 & 0.27 to 2.3 & \\
\hline BMI $\left(\mathrm{kg} / \mathrm{m}^{2}\right)$ & & & & 0.08 \\
\hline Underweight/normal $(<25)$ & $94(23)$ & 1.00 & reference & \\
\hline Overweight $(25$ to $<30)$ & $123(30)$ & 1.00 & 0.51 to 2.1 & \\
\hline Obesity I ( 30 to <35) & $111(27)$ & 0.69 & 0.33 to 1.5 & \\
\hline Obesity II (35 to <40) & $51(13)$ & 0.85 & 0.35 to 2.07 & \\
\hline Obesity III ( $\geq 40)$ & $29(7)$ & 0.86 & 0.29 to 2.6 & \\
\hline Age (years) & & & & 0.22 \\
\hline$\leq 50$ (premenopausal) & $120(29)$ & 1.40 & 0.81 to 2.4 & \\
\hline$>50$ (postmenopausal) & $295(71)$ & 1.00 & reference & \\
\hline
\end{tabular}

Sadjusted for age, race/ethnicity and BMI; * for test of model with and without the characteristic $\mathrm{BMl}=$ body mass index; $\mathrm{Cl}=$ confidence interval.

this subgroup to the rest of the black population. Controlling for age ( $\leq 50$ years vs $>50$ years), no significant differences were seen between Caribbean black women and other black women in the proportion of triple-negative tumours, BMI, grade or node involvement (see Additional Data File 1).

\section{Discussion}

We investigated clinicopathological features of breast cancers in a patient population unusual for its racial/ethnic and socioeconomic diversity. We focused on triple-negative tumours. Our results confirmed previously described associations between patient and tumour characteristics, and uncovered new associations. In particular, we found a three-fold increased prevalence of triple-negative tumours in black women, who comprised $43 \%$ of our patients compared with non-black women. Triple-negative tumours comprised equal fractions - approximately 30\% - of breast cancers in younger and older black women, regardless of their likely menopausal status. Triple-negative tumours comprised equal fractions about 30\% - of breast cancers in obese and in non-obese black women. Considering all women together, regardless of race/ethnicity and age, we did note a trend toward an inverse association between triple-negative tumours and elevated BMI. Overall, these results suggest that black women of diverse backgrounds are much more likely to be diagnosed with triple-negative tumours, and therefore a poorer prognosis, regardless of older age or higher BMI, factors that in other populations may be associated with hormone receptor-positive tumours with a better prognosis.
Our observation that both younger and older black women have increased, equivalent proportions of triple-negative tumours contrasts with results from the Carolina Breast Cancer Study. That study found a higher prevalence of basal-like tumours only in premenopausal African-American patients [6]. The contrast may be due to the unusual heterogeneity of our population, with consequent diversity of socioeconomic, lifestyle and genetic factors. Our study highlights the complexity surrounding the issue of race/ethnicity in medical research, and the potential differences in how each can be defined, measured and interpreted [41,42]. The contrast could also reflect differences between the tumours that were studied. We defined tumours by a triple-negative phenotype and did not routinely determine if they were basal-like. The triple-negative tumours we could examine further showed morphological and immunohistochemical characteristics (i.e., medullary features and increased CK5/6 and EGFR staining) in proportions similar to what has been reported elsewhere, and are consistent with estimates that 80 to $90 \%$ of triple-negative tumours are basal-like [43-45].

Perhaps our most intriguing result is the relation between BMI and tumour subtype. Existing studies reveal a complicated relation between BMI and breast cancer. Some studies find associations between increased BMl and increased risk of developing breast cancer, higher stage at diagnosis, greater likelihood of expressing markers of high cell proliferation, poorer response to neodjuvant chemotherapy and increased disease-specific mortality [46-51]. On the other hand, there is 
a clear association between elevated BMI and postmenopausal, ER-positive and PR-positive breast cancers [52], perhaps due to oestrogen production from adipose tissue. If obesity is important in determining hormone receptor status, then obese black and non-black women should have similar proportions of hormone receptor-negative tumours. However, we find that obese black women have four-fold more triple-negative tumours than obese non-black women. Therefore, factors other than whole body obesity must be crucial in determining hormone receptor expression. A specific type of obesity, an elevated waist:hip ratio, was associated with the basal subtype in the Carolina dataset [40], but overall, the factors that determine subtype - genetics, microenvironment, environmental or developmental exposures - remain unclear.

The lack of association between obesity and hormone receptor expression in black women may contribute to our observation that, when we considered all 415 cases, we found a trend, rather than a significant association, between increased BMI category and decreased proportions of triple-negative tumours. The inclusion of a large subset of black women $(43 \%)$, for whom increased BMl is not clearly associated with hormone receptor positivity, in the dataset may prevent us from seeing the association reported in other populations between increased BMI and hormone receptor positivity.

Our observations are consistent with the lack of association seen between BMl and overall risk of postmenopausal breast cancer in the Black Women's Health Study [15]. Those authors speculated that if obesity confers mainly a risk of hormone receptor-positive tumours, then it would be difficult to detect an association between elevated BMI and postmenopausal breast cancer if a large proportion of the black women's cancers were hormone receptor negative. This is precisely our finding. Our observations are also consistent with observations that high BMI is associated with hormone receptor-negative tumours in cohorts of different ethnic composition [50,53].

Potential limitations of our study include its relatively small size and lack of data on clinical outcome or on potential confounders, such as parity. These limitations, however, are balanced by strengths: the unusual, highly heterogeneous population, data extraction from computerised records augmented with manual abstraction for quality control, and a consistent, singleinstitution approach to pathological diagnosis and patient care. Although we do not have the socioeconomic status of each patient, the population in the database is highly likely to reflect the institution's overall socioeconomic status data. These strengths contributed to our database confirming many previously noted associations between clinical and pathological features.

The observations we report from this database have potential clinical implications. Several studies have documented the poor outcome of patients with triple-negative or basal-like tumours $[35,38]$, and the greater mortality of black women with breast cancer compared with other women, regardless of age $[6,35,38]$. Our findings that a diverse group of both younger and older, normal-weight and obese, black women have approximately three-fold more triple-negative tumours than other groups, may be one factor contributing to the unfavourable prognosis of black women with breast cancer.

\section{Conclusion}

Black women of diverse background have three-fold more triple-negative tumours than non-black women, regardless of age and BMI. Other factors must determine tumour subtype. The higher prevalence of triple-negative tumours in black women in all age and weight categories is likely to contribute to a black women's unfavourable breast cancer prognosis.

\section{Competing interests}

The authors declare that they have no competing interests.

\section{Authors' contributions}

LS contributed to the study's conception and design, data collection and analysis, and manuscript writing. TL contributed to the study's data collection and analysis and manuscript writing. JW and DC contributed to the study's conception and design, and to data collection and analysis. JS, RB and MC contributed to the study's data collection and assembly. JCL contributed to the study's design, data collection and analysis and contributed to the manuscript writing. TK contributed to the study's conception and design, data collection and analysis, and manuscript writing. CLR contributed to the study's conception and design, provided financial support, data analysis and interpretation and manuscript writing.

\section{Additional files}

The following Additional files are available online:

\section{Additional file 1}

A word file containing a table that lists the associations between patient and tumour characteristics in Caribbean black women vs other black women.

See http://www.biomedcentral.com/content/ supplementary/bcr2242-S1.doc

\section{Acknowledgements}

This study was supported by The LaPann Fund and the Research Enhancement Fund. It was presented in part at the San Antonio Breast Cancer Symposium, San Antonio, TX, USA, 16 December, 2006, Abstract \#3501. We thank Julie R Palmer, ScD, and Lynn Rosenberg, $\mathrm{ScD}$, for thoughtful comments on the manuscript; and Paul Brodwin, $\mathrm{PhD}$, for helpful discussions. 


\section{References}

1. Chlebowski RT, Chen Z, Anderson GL, Rohan T, Aragaki A, Lane D, Dolan NC, Paskett ED, McTiernan A, Hubbell FA, AdamsCampbell LL, Prentice R: Ethnicity and breast cancer: factors influencing differences in incidence and outcome. J Nat/ Cancer Inst 2005, 97:439-448.

2. Korsching E, Packeisen J, Agelopoulos K, Eisenacher M, Voss R, Isola J, van Diest PJ, Brandt B, Boecker W, Buerger H: Cytogenetic alterations and cytokeratin expression patterns in breast cancer: integrating a new model of breast differentiation into cytogenetic pathways of breast carcinogenesis. Lab Invest 2002, 82:1525-1533.

3. Livasy CA, Karaca G, Nanda R, Tretiakova MS, Olopade OI, Moore DT, Perou CM: Phenotypic evaluation of the basal-like subtype of invasive breast carcinoma. Mod Pathol 2006, 19:264-271.

4. Foulkes WD, Stefansson IM, Chappuis PO, Begin LR, Goffin JR, Wong N, Trudel M, Akslen LA: Germline BRCA1 mutations and a basal epithelial phenotype in breast cancer. I Natl Cancer Inst 2003, 95:1482-1485.

5. Perou CM, Sorlie T, Eisen MB, Rijn M van de, Jeffrey SS, Rees CA, Pollack JR, Ross DT, Johnsen H, Akslen LA, Fluge O, Pergamenschikov A, Williams C, Zhu SX, Lønning PE, Børresen-Dale AL, Brown PO, Botstein D: Molecular portraits of human breast tumours. Nature 2000, 406:747-752.

6. Carey LA, Perou CM, Livasy CA, Dressler LG, Cowan D, Conway K, Karaca G, Troester MA, Tse CK, Edmiston S, Deming SL, Geradts J, Cheang MC, Nielsen TO, Moorman PG, Earp HS, Millikan RC: Race, breast cancer subtypes, and survival in the Carolina Breast Cancer Study. J Am Med Assoc 2006, 295:2492-2502.

7. Suzuki R, Rylander-Rudqvist T, Ye W, Saji S, Wolk A: Body weight and postmenopausal breast cancer risk defined by estrogen and progesterone receptor status among Swedish women: A prospective cohort study. Int J Cancer 2006, 119:1683-1689.

8. Ahn J, Schatzkin A, Lacey JV Jr, Albanes D, Ballard-Barbash R, Adams KF, Kipnis V, Mouw T, Hollenbeck AR, Leitzmann MF: Adiposity, adult weight change, and postmenopausal breast cancer risk. Arch Intern Med 2007, 167:2091-2102.

9. Carmichael AR: Obesity as a risk factor for development and poor prognosis of breast cancer. BJOG 2006, 113:1160-1166.

10. Cleveland RJ, Eng SM, Abrahamson PE, Britton JA, Teitelbaum SL, Neugut Al, Gammon MD: Weight gain prior to diagnosis and survival from breast cancer. Cancer Epidemiol Biomarkers Prev 2007, 16:1803-1811

11. Loi S, Milne RL, Friedlander ML, McCredie MR, Giles GG, Hopper $\mathrm{JL}$, Phillips KA: Obesity and outcomes in premenopausal and postmenopausal breast cancer. Cancer Epidemiol Biomarkers Prev 2005, 14:1686-1691.

12. Hunter DJ, Willett WC: Diet, body size, and breast cancer. Epidemiol Rev 1993, 15:110-132.

13. Lahmann $\mathrm{PH}$, Hoffmann $\mathrm{K}$, Allen $\mathrm{N}$, van Gils $\mathrm{CH}$, Khaw $\mathrm{KT}$, Tehard $B$, Berrino F, Tjønneland A, Bigaard J, Olsen A, Overvad K, ClavelChapelon F, Nagel G, Boeing $H$, Trichopoulos D, Economou G, Bellos G, Palli D, Tumino R, Panico S, Sacerdote C, Krogh V, Peeters PH, Bueno-de-Mesquita HB, Lund E, Ardanaz E, Amiano $P$, Pera G, Quirós JR, Martínez C, Tormo MJ, Wirfält E, Berglund G, Hallmans G, Key TJ, Reeves G, Bingham S, Norat T, Biessy C, Kaaks R, Riboli $E$ : Body size and breast cancer risk: findings from the European Prospective Investigation into Cancer And Nutrition (EPIC). Int J Cancer 2004, 111:762-771.

14. Brandt PA van den, Spiegelman D, Yaun SS, Adami HO, Beeson L, Folsom AR, Fraser G, Goldbohm RA, Graham S, Kushi L, Marshall JR, Miller AB, Rohan T, Smith-Warner SA, Speizer FE, Willett WC, Wolk A, Hunter DJ: Pooled analysis of prospective cohort studies on height, weight, and breast cancer risk. Am J Epidemiol 2000, 152:514-527.

15. Palmer JR, Adams-Campbell LL, Boggs DA, Wise LA, Rosenberg $\mathrm{L}$ : A prospective study of body size and breast cancer in black women. Cancer Epidemiol Biomarkers Prev 2007, 16:1795-1802.

16. Magnusson CM, Roddam AW, Pike MC, Chilvers C, Crossley B, Hermon C, McPherson K, Peto J, Vessey M, Beral V: Body fatness and physical activity at young ages and the risk of breast cancer in premenopausal women. Br J Cancer 2005, 93:817-824.
17. Weiderpass $E$, Braaten $T$, Magnusson $C$, Kumle $M$, Vainio $H$, Lund $\mathrm{E}$, Adami HO: A prospective study of body size in different periods of life and risk of premenopausal breast cancer. Cancer Epidemiol Biomarkers Prev 2004, 13:1121-1127.

18. Eng SM, Gammon MD, Terry MB, Kushi LH, Teitelbaum SL, Britton $\mathrm{JA}$, Neugut Al: Body size changes in relation to postmenopausal breast cancer among women on Long Island, New York. Am J Epidemiol 2005, 162:229-237.

19. Rock CL, Demark-Wahnefried W: Nutrition and survival after the diagnosis of breast cancer: a review of the evidence. J Clin Oncol 2002, 20:3302-3316.

20. Ghafoor A, Jemal A, Ward E, Cokkinides V, Smith R, Thun M: Trends in breast cancer by race and ethnicity. CA Cancer $J$ Clin 2003, 53:342-355.

21. Cross CK, Harris J, Recht A: Race, socioeconomic status, and breast carcinoma in the U.S: what have we learned from clinical studies. Cancer 2002, 95:1988-1999.

22. Jatoi $\mathrm{I}$, Becher $\mathrm{H}$, Leake $\mathrm{CR}$ : Widening disparity in survival between white and African-American patients with breast carcinoma treated in the U. S. Department of Defense Healthcare system. Cancer 2003, 98:894-899.

23. Rose DP, Royak-Schaler R: Tumour biology and prognosis in black breast cancer patients: a review. Cancer Detect Prev 2001, 25:16-31.

24. Adams-Campbell LL, Kim KS, Dunston G, Laing AE, Bonney G, Demenais $F$ : The relationship of body mass index to reproductive factors in pre- and postmenopausal African-American women with and without breast cancer. Obes Res 1996, 4:451-456.

25. Hall IJ, Newman B, Millikan RC, Moorman PG: Body size and breast cancer risk in black women and white women: the Carolina Breast Cancer Study. Am J Epidemiol 2000, 151:754-764.

26. Schatzkin A, Palmer JR, Rosenberg L, Helmrich SP, Miller DR Kaufman DW, Lesko SM, Shapiro S: Risk factors for breast cancer in black women. J Natl Cancer Inst 1987, 78:213-217.

27. Dowsett M, Bartlett J, Ellis IO, Salter J, Hills M, Mallon E, Watters AD, Cooke T, Paish C, Wencyk PM, Pinder SE: Correlation between immunohistochemistry (HercepTest) and fluorescence in situ hybridization (FISH) for HER-2 in 426 breast carcinomas from 37 centres. J Pathol 2003, 199:418-423.

28. Wolff AC, Hammond ME, Schwartz JN, Hagerty KL, Allred DC Cote RJ, Dowsett M, Fitzgibbons PL, Hanna WM, Langer A, McShane LM, Paik S, Pegram MD, Perez EA, Press MF, Rhodes A, Sturgeon C, Taube SE, Tubbs R, Vance GH, Vijver M van de, Wheeler TM, Hayes DF, American Society of Clinical Oncology; College of American Pathologists: American Society of Clinical Oncology/College of American Pathologists quideline recommendations for human epidermal growth factor receptor 2 testing in breast cancer. J Clin Oncol 2007, 25:118-145.

29. Greene FL, Page DL, Fleming ID, Fritz A, Balch CM, Haller DG, Morrow M: AJCC Cancer Staging Manual. 6th edition. New York: Springer; 2002.

30. Allred DC, Harvey JM, Berardo M, Clark GM: Prognostic and predictive factors in breast cancer by immunohistochemical analysis. Mod Pathol 1998, 11:155-168.

31. Henriksen KL, Rasmussen BB, Lykkesfeldt AE, Moller S, Ejlertsen $B$, Mouridsen HT: Semi-quantitative scoring of potentially predictive markers for endocrine treatment of breast cancer: a comparison between whole sections and tissue microarrays. $J$ Clin Pathol 2007, 60:397-404.

32. SEER Cancer Statistics Review, 1975-2005, National Cancer Institute [http://seer.cancer.gov/csr/1975 2005/]

33. Breast Cancer Facts \& Figures 2007-2008. Atlanta: American Cancer Society, Inc; 2007.

34. Lund MJ, Butler EN, Bumpers HL, Okoli J, Rizzo M, Hatchett N, Green VL, Brawley OW, Oprea-llies GM, Gabram SG: High prevalence of triple-negative tumours in an urban cancer center. Cancer 2008, 113:608-615.

35. Lund MJ, Trivers KF, Porter PL, Coates RJ, Leyland-Jones B, Brawley OW, Flagg EW, O'Regan RM, Gabram SG, Eley JW: Race and triple negative threats to breast cancer survival: a populationbased study in Atlanta, GA. Breast Cancer Res Treat 2009, 113:357-370.

36. Morris GJ, Naidu S, Topham AK, Guiles F, Xu Y, McCue P, Schwartz GF, Park PK, Rosenberg AL, Brill K, Mitchell EP: Differences in breast carcinoma characteristics in newly diagnosed 
African-American and Caucasian patients: a single-institution compilation compared with the National Cancer Institute's Surveillance, Epidemiology, and End Results database. Cancer 2007, 110:876-884.

37. Rose DP, Haffner SM, Baillargeon J: Adiposity, the metabolic syndrome, and breast cancer in African-American and white American women. Endocrine Rev 2007, 28:763-777.

38. Bauer KR, Brown M, Cress RD, Parise CA, Caggiano V: Descriptive analysis of estrogen receptor (ER)-negative, progesterone receptor (PR)-negative, and HER2-negative invasive breast cancer, the so-called triple-negative phenotype: a populationbased study from the California cancer Registry. Cancer 2007, 109:1721-1728.

39. Brown M, Tsodikov A, Bauer KR, Parise CA, Caggiano V: The role of human epidermal growth factor receptor 2 in the survival of women with estrogen and progesterone receptor-negative, invasive breast cancer: the California Cancer Registry, 19992004. Cancer 2008, 112:737-747.

40. Millikan RC, Newman B, Tse CK, Moorman PG, Conway K, Smith LV, Labbok MH, Geradts J, Bensen JT, Jackson S, Nyante S, Livasy C, Carey L, Earp HS, Perou CM: Epidemiology of basal-like breast cancer. Breast Cancer Res Treat 2008, 109:123-139.

41. Mountain JL, Risch N: Assessing genetic contributions to phenotypic differences among 'racial' and 'ethnic' groups. Nat Genet 2004, 36(Suppl):S48-53.

42. Schwartz RS: Racial profiling in medical research. New Eng/ J Med 2001, 344:1392-1393.

43. Kreike $B$, van Kouwenhove $M$, Horlings $H$, Weigelt $B$, Peterse $H$, Bartelink H, Vijver MJ van de: Gene expression profiling and histopathological characterization of triple-negative/basal-like breast carcinomas. Breast Cancer Res 2007, 9:R65.

44. Rakha EA, El-Sayed ME, Green AR, Lee AH, Robertson JF, Ellis IO: Prognostic markers in triple-negative breast cancer. Cancer 2007, 109:25-32.

45. Rakha EA, Reis-Filho JS, Ellis IO: Basal-like breast cancer: a critical review. J Clin Oncol 2008, 26:2568-2581.

46. Daling JR, Malone KE, Doody DR, Johnson LG, Gralow JR, Porter PL: Relation of body mass index to tumour markers and survival among young women with invasive ductal breast carcinoma. Cancer 2001, 92:720-729.

47. Lahmann PH, Lissner L, Berglund G: Breast cancer risk in overweight postmenopausal women. Cancer Epidemiol Biomarkers Prev 2004, 13:1414.

48. Whiteman MK, Hillis SD, Curtis KM, McDonald JA, Wingo PA, Marchbanks PA: Body mass and mortality after breast cancer diagnosis. Cancer Epidemiol Biomarkers Prev 2005, 14:2009-2014.

49. Zhang S, Folsom AR, Sellers TA, Kushi LH, Potter JD: Better breast cancer survival for postmenopausal women who are less overweight and eat less fat. The lowa Women's Health Study. Cancer 1995, 76:275-283.

50. Litton JK, Gonzalez-Angulo AM, Warneke CL, Buzdar AU, Kau SW, Bondy M, Mahabir S, Hortobagyi GN, Brewster AM: Relationship between obesity and pathologic response to neoadjuvant chemotherapy among women with operable breast cancer. J Clin Oncol 2008, 26:4072-4077.

51. Kerlikowske K, Walker R, Miglioretti DL, Desai A, Ballard-Barbash R, Buist DS: Obesity, mammography use and accuracy, and advanced breast cancer risk. J Natl Cancer Inst 2008, 100:1724-1733.

52. Suzuki R, Orsini N, Saji S, Key TJ, Wolk A: Body weight and incidence of breast cancer defined by estrogen and progesterone receptor status - a meta-analysis. Int J Cancer 2009, 124:698-712.

53. Yang XR, Pfeiffer RM, Garcia-Closas M, Rimm DL, Lissowska J, Brinton LA, Peplonska B, Hewitt SM, Cartun RW, Mandich D, Sasano $H$, Evans DB, Sutter TR, Sherman ME: Hormonal markers in breast cancer: coexpression, relationship with pathologic characteristics, and risk factor associations in a populationbased study. Cancer Res 2007, 67:10608-10617. 